\title{
Electrically Driven VTOL Flying Car Designing and Aerodynamic Analysis
}

\author{
Metin Uzun ${ }^{1 *}$, Sezer Çoban ${ }^{2}$ \\ ${ }^{1}$ İskenderun Technical University, Faculty of Aeronautics and Astronautics, Aircraft Maintenance and Repair Department, Hatay, Türkiye, (ORCID: 0000-0002-0744- \\ 3491), metin.uzun@iste.edu.tr \\ ${ }^{2}$ İskenderun Technical University, Faculty of Aeronautics and Astronautics, Aircraft Maintenance and Repair Department, Hatay, Türkiye, (ORCID: 0000-0001-6750- \\ 5001), sezer.coban@iste.edu.tr
}

(First received 6 April 2021 and in final form 16 August 2021)

(DOI: $10.31590 /$ ejosat.910516)

ATIF/REFERENCE: Uzun, M. Coban, S. (2021). Electrically Driven VTOL Flying Car Designing and Aerodynamic Analysis. Avrupa Bilim ve Teknoloji Dergisi, (25), 815-821.

\begin{abstract}
In this study, the design of the electric powered VTOL Flying car was made in the CAD program, and the longitudinal, vertical and lateral flight dynamics were examined and aerodynamic analysis was made. In the design, the power and propulsion systems of the flying car, avionic systems, security systems, magnetic sensors, navigation landing and take-off methods, requirement verification methods, flight performance values were determined. Our design work for flying cars, which will soon start real-time flights, will guide the people and institutions that will design and produce in this field.

A practical flying car should be able to operate safely and environmentally both in public spaces and in the air. For widespread adoption, it must be able to fly without a qualified pilot as we know it as a controller, and must have appropriate purchase and operating costs. Being a qualified car driver and having a pilot license, which certification processes are extremely difficult, is an important obstacle to the adoption and widespread process of the flying car concept. The certification processes of many different countries have been examined for the flying car we will design. Examination of these processes has been guiding in the creation of detailed data on many issues, and in this context, care has been taken to meet the requested competencies on a common ground. In order to overcome these procedures, a VTOL platform with high autonomy has been designed thanks to its subsystems as well as a stable flight dynamics.
\end{abstract}

Keywords: Flying Car, Design, Aerodynamic.

\section{Elektrikle Çalışan VTOL Uçan Araba Tasarımı ve Aerodinamik Analizi}

$\ddot{O} \mathbf{z}$

$\mathrm{Bu}$ çalışmada, elektrikle çalışan VTOL Uçan arabanın tasarımı CAD programında yapılarak boylamsal, dikey ve yanal uçuş dinamikleri incelenerek aerodinamik analizleri yapılmıştır. Tasarımda uçan arabanın güç ve tahrik sistemleri, aviyonik sistemler, güvenlik sistemleri, manyetik sensörler, seyrüsefer iniş ve kalkış yöntemleri, gereksinim doğrulama yöntemleri, uçuş performans değerleri belirlendi. Yakında gerçek zamanlı uçuşlara başlayacak olan uçan arabalara yönelik tasarım çalışmalarımız, bu alanda tasarım ve üretim yapacak kişi ve kurumlara yol gösterecek.

Pratik bir uçan araba, hem kamusal alanlarda hem de havada güvenli ve çevreci bir şekilde çalışabilmelidir. Yaygın olarak benimsenmesi için, kontrolör olarak bildiğimiz nitelikli bir pilot olmadan uçabilmesi ve uygun satın alma ve işletme maliyetlerine sahip olması gerekir. Sertifikasyon süreçleri son derece zor olan kalifiye araç sürücüsü ve pilot ehliyetine sahip olmak, uçan araba kavramının benimsenmesi ve yaygınlaşmasının önünde önemli bir engeldir. Tasarlayacağımız uçan araba için birçok farklı ülkenin sertifikasyon süreçleri incelendi. Bu süreçlerin incelenmesi birçok konuda detaylı verilerin oluşturulmasında yol gösterici olmuş ve bu kapsamda talep edilen yetkinliklerin ortak bir paydada karşılanmasına özen gösterilmiştir. Bu prosedürlerin üstesinden gelebilmek için alt sistemleri ve stabil uçuş dinamiği sayesinde yüksek otonomiye sahip bir VTOL platformu tasarlanmıştır.

Anahtar Kelimeler: Uçan Araba, Tasarım, Aerodinamik

*Corresponding Author: metin.uzun@iste.edu.tr 


\section{Introduction}

A practical flying car should be able to operate safely and environmentally both in public spaces and in the air. For widespread adoption, it must be able to fly without a qualified pilot as we know it as a controller, and must have appropriate purchase and operating costs. Being a qualified car driver and having a pilot language, for which certification processes are extremely difficult, are an important obstacle to the adoption and widespread process of the flying car concept. The certification processes of many different countries have been examined for the flying car we designed. Examination of these processes has been guiding in the creation of detailed data on many issues, and in this context, care has been taken to meet the requested competencies on a common ground. In order to overcome these procedures, a VTOL (Vertical Take-off Landing) platform with high autonomy has been designed thanks to its subsystems, as well as a stable flight dynamics.

During the design phase of flying cars, aerodynamics and mechanical parts should be evaluated according to the determined needs and conditions, and the choices should be made by considering the alternatives. The fulfillment of this condition is directly related to the design of the software and hardware systems that will determine the characteristics of flying cars and will be planned in the next step. On this basis, mechanical components and aerodynamic calculations can be evaluated under three main headings; Airframe / Wing, Engine / Propeller Aircraft-Land Vehicle Configuration. Aerodynamic forces that should be considered before selecting these components; Lift, Thrust, Gravity and Drag, and these calculations are based on the "Mathematical Aerodynamic Description" obtained by long years of wind tunnel tests on hundreds of wing shapes. has been made. In addition, high-speed land transportation vehicles are subjected to aerodynamic analysis as they are exposed to air loads such as airplanes and similar vehicles. The two most important problems for these vehicles are increased energy consumption and instability due to resistance. The instability is mainly due to the inability of such vehicles to grip the ground well due to aerodynamic transport. In addition, the vortices formed by the separation of the surfaces create vibration, making it difficult to control land vehicles and also negatively affect the comfort. The design of aerodynamic and mechanical systems has been improved by taking all these data into consideration [1-15].

\section{Material and Method}

\subsection{Aerodynamic Analysing of Flying Car}

When the literature is examined, it is known that the boundary conditions, from the trailing edge of the wing for numerical solution, should be left 20 times the size of the wing veterinarian, and 15 times the wing veter size in the lower and upper parts of the wing. Figure 1 shows the boundary conditions image for this study. In the definition of boundary conditions, the region where the free flow velocity meets the wing leading edge is defined as the velocity inlet, the area where the flow is separated as the pressure outlet and the other surfaces as the wall.

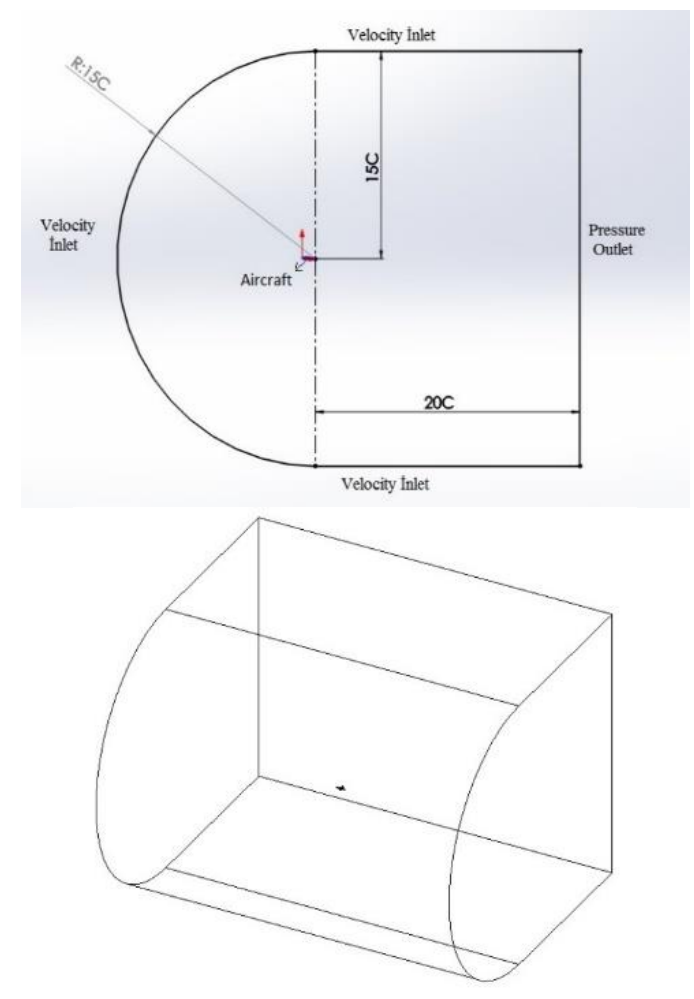

Figure 1. Boundary Conditions

\subsubsection{Mesh Properties}

Boundary layer creation is one of the most important parts of networking. In order to observe the aerodynamic effects and to obtain the results accurately, the first coat thickness $(\mathrm{Y}+)$ and the total thickness $(\delta)$ must be calculated. The Schlichting surface friction formula was used to estimate the local surface friction for a turbulent boundary layer [16]. Valid for $\operatorname{Re}<109$.

$\mathrm{Y}+$ calculation:

Re number calculation:

$\operatorname{Re}=\frac{\rho . U . L}{\mu}$

Surface Drag Calculation:

$C_{f}=\left[2 \log _{10}\left(\operatorname{Re}_{x}\right)-0,3\right]^{-2,3} \operatorname{Re} \leq 10^{9} i c ̧ i n$

Wall shear stress:

$\tau_{w}=C_{f} \cdot \frac{1}{2} \rho U_{\text {serbestaks }}^{2}$

Friction Speed:

$u_{*}=\sqrt{\frac{\tau_{\omega}}{\rho}}$

Wall calculation: 
$y=\frac{y^{+} \mu}{\rho u_{*}}$

The first boundary layer thickness estimated according to the above equations is taken as 0.00015 . Laminar boundary layer thickness is determined using the following equation [17].

$\delta=\frac{5.0 x}{\sqrt{\mathrm{Re}_{x}}}$

Mesh properties are given in table 1.

Table 1. Mesh Properties

\begin{tabular}{|l|l|}
\hline Face Sizing & $0,025 \mathrm{~m}$ \\
\hline Edge Sizing & $0,02 \mathrm{~m}$ \\
\hline Max Size & 0,2 \\
\hline Skewness & 0,815 \\
\hline Orthogonal Quality & 0,215 \\
\hline Mesh Element Number & 2600000 \\
\hline
\end{tabular}

\subsection{Flying Car Design and Manufacturability}

As in every mechanical design, the financial resource needed for the designs made for flying car systems to be put into production after certain tests and safety criteria are met should be evaluated within the scope of production budgets. It is aimed to index the production cost to a minimum as a result of comparisons we made with the production costs of similar technologies and systems in the aviation field by making many plans in a way that does not pose any threat to the system, and calculating the production costs and times for the systems decided to be used, and the necessary arrangements have been made on the design in this direction. During the design and development process of the product, systematic consideration of production-related issues in a way to facilitate the manufacture and assembly of product components, designs that facilitate production were emphasized and material selection was made accordingly. Flying car technical CAD drawings are shown in figure 2.
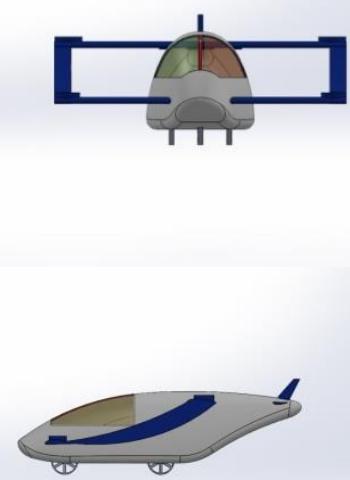
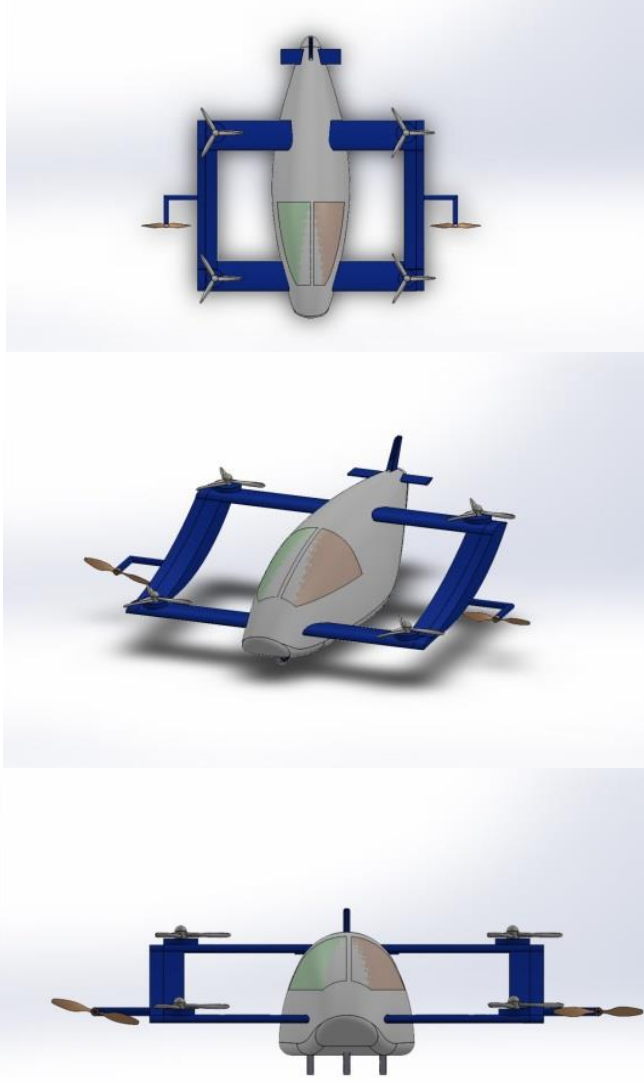

Figure 2. Flying car technical drawings

\subsection{Power and Propulsion Systems}

The configuration of the propulsion system in flying car design has two stages. During its use as an aircraft, the mathematical model related to the carrier 4 DC motors is specified in the aerodynamics section. In addition, it has been determined that propeller designs create significant differences on bearing forces. In this context, it is planned to make an original propeller design and a special dimensioning system for the vehicle. As a result of researches, the engine selection to be used while the land vehicle is standing was determined as Hub engine. HUB motors are ideal for direct starting to the wheels of electric vehicles. Also, it is long-lasting due to its brushless nature. Since there is no connection in the transmission of electrical energy to the motor in brushless HUB motors, there are no parts that wear out by friction. In terms of energy, since it operates with direct current, the battery units to be placed in the vehicles can be used without any conversion. The wheel, which is one of the biggest forces affecting vehicle power and propulsion, consumes $20 \%$ of the engine power alone in different designs. The speed of our vehicle, acceleration, acceleration, stopping distance etc. Such factors depend heavily on the wheel parameters. as the road friction coefficient 0.035 for highways acceptable edilmişit in Turkey. Considering these data, some choices have been made for the selection of wheels. Its diameter is taken as 20.86 ". Considering these calculations, the type of battery to be selected was initially determined as li-on. However, research on a battery-battery hybrid systems in which two different battery types are used are ongoing. Investigated; The efficiency of these and similar hybrid battery models with an LTO battery, a DC / 
DC converter and an NMC battery in each level is calculated. Technical specifications of VTOL Engine, Electronic Speed Controller (ESC) and Lipo Battery are given in table 2.

Table 2. Technical specifications of VTOL Engine, Electronic Speed Controller (ESC) and Lipo Battery

\begin{tabular}{|c|c|c|c|c|c|}
\hline & Type & $\begin{array}{l}\text { Weight } \\
(\mathrm{g})\end{array}$ & $\begin{array}{l}\text { Maximum } \\
\text { Thrust }(g)\end{array}$ & $\begin{array}{l}\text { Current } \\
(A)\end{array}$ & $\begin{array}{l}\text { Voltage } \\
(V)\end{array}$ \\
\hline $\begin{array}{l}\text { VTOL } \\
\text { Engine }\end{array}$ & $\begin{array}{l}\text { U15 II } \\
\text { KV100 }\end{array}$ & $1740 * 4$ & 35500 & 110.4 & 44,4 \\
\hline $\begin{array}{l}\text { Thrust } \\
\text { Engine }\end{array}$ & $\begin{array}{l}\text { F1000 } \\
\text { KV510 }\end{array}$ & $400 * 2$ & 5000 & 45 & 46 \\
\hline \multirow{2}{*}{$\begin{array}{l}\text { Electronic } \\
\text { Speed } \\
\text { Controller } \\
(\text { ESC })\end{array}$} & Type & $\begin{array}{l}\text { Weight } \\
(g r)\end{array}$ & $\begin{array}{l}\text { Continuous } \\
\text { Current } \\
\text { (A) }\end{array}$ & $\begin{array}{l}\text { Peak } \\
\text { Current } \\
\text { (A) }\end{array}$ & Lipo \\
\hline & $\begin{array}{l}\text { Flame } \\
80 \mathrm{~A} \\
\mathrm{HV} \\
\end{array}$ & 106 & 80 & 120 & $6-12 S$ \\
\hline \multirow[t]{2}{*}{$\begin{array}{l}\text { Lipo } \\
\text { Battery }\end{array}$} & Type & $\begin{array}{l}\text { Weight } \\
(g r)\end{array}$ & Capacity & & $\begin{array}{l}\text { Voltage } \\
(V)\end{array}$ \\
\hline & $\begin{array}{l}12 \mathrm{~s} \\
\text { Lipo } \\
\text { Battery } \\
\end{array}$ & 4825 & $21000 \mathrm{mAh}$ & & $44,4 \mathrm{~V}$ \\
\hline
\end{tabular}

Brushless motors are being used in many fields with the developing technology, and they have started to be used in the robotic field. These motors are used frequently with radio control. One of the main reasons for their use in this area is their high performance compared to other engines. The advantages of brushless motors such as quieter operation compared to other motors, not creating electrical noise, easier maintenance, longer life, faster operation and having stronger torques have been the criteria that affect our choice. Brushless motors are divided into two groups according to their internal structure: inline brushless motors and outline brushless motors: Outline brushless motors have the rotor part on the outer side and the stator part on the inner side. Stator part is fixed, rotor part is fixed. The characteristics of Outline motors are the opposite of those of Inline motors. Their speed is low but their torque per voltage is higher. For this reason, these engines are used in aircraft[18]. The engine generates the force that enables the flying car to move forward, generate transport and take off, and what is required for land driving. Outrunner Brushless Motor dimensions determine the power of the motor, generating high torque per voltage for the purpose of high speed, efficiency and torque. As the efficiency increases as the motor grows, the optimum value should be chosen since the current drawn in idle will also increase. The working principle of ESC circuits is to send PWM waves to the windings of the motors sequentially. Brushed motors are DC motors and driven by ESC from 2 ends. But brushless motors are three-phase motors and are driven from 3 ends. ESCs used in these motors have a more complex structure than ESCs used in DC motors. They send the DC voltage received from the 2 ends of the battery to the motor as AC with 3 cables. ESCs used for brushless motors work like a frequency converter. They change the number of revolutions depending on the frequency, not the voltage[19]. Esc has been selected with the power to supply the required current to the motor. According to the calculations made, ESC was selected according to the amount of amperes drawn in the maximum gas.
$F=1,225 \frac{\pi(0,0254 \cdot d)^{2}}{4}\left[\begin{array}{l}\left(R P M \cdot 0,0254 \cdot \text { pitch } \cdot \frac{1}{60}\right)^{2}- \\ \left(R P M \cdot 0,0254 \cdot \text { pitch } \cdot \frac{1}{60}\right) \cdot V_{0}\end{array}\right] \cdot\left(\frac{d}{3,29546 \cdot \text { pitch }}\right)^{1,5}$

$F=4,392399 \times 10^{8} \cdot R P M \cdot \frac{d^{3,5}}{\sqrt{\text { pitch }}} \cdot\left(4,23333 \times 10^{-4} \cdot R P M \cdot p i t c h-* V_{0}\right)$

\subsection{Avionic Systems}

Pixhawk Cube 2 is the component that will be used for flight control and is the most basic component of the system. Understandable and detailed interface, software programmable and autonomous driving are some of the advantages it provides to us. The fact that it supports both air and land vehicles is one of the most important factors in choosing this controller. It is a serious advantage that the communication protocol (MavLink) it uses allows the use and development / adaptation of the UAVCAN system, which is a protocol designed for reliable intraveicular communication in aviation and robotic applications, by using the uORB and CAN bus that provides intermediate data transmission. In addition to these protocols, which were created to eliminate the difficulty of the built-in data exchange between the systems and components of the new generation smart vehicles, the width of the sensor range it supports and the ability to communicate with different controllers (Raspberry, Arduino, Jetson TX series) enable the process to proceed in a more secure and systematic way. The auxiliary controllers and sensors to be used will be explained in detail along with their intended use in the following sections of the study.

The total weight of our electric vehicle has been calculated as approximately $110 \mathrm{~kg}$ and the capacity of our vtol engines has been determined as $140 \mathrm{~kg}$. In addition, the thrust power of our vehicle's forward thruster engines, which will be activated after reaching a certain altitude with vtol engines, is preferred as 10 $\mathrm{kg}$. Detailed information of compatible esc and lipo batteries for our vtol motors and thruster motors are given in table 2 .

\subsection{Security Systems}

Reliability "is the ability or possibility of a system / tool / equipment to perform and maintain the function expected of it under specified conditions and for a specified period of time. Reliability is expressed in numerical percentage as the probability of operating without failure for a specified period of time. One of the most sensitive points of flying cars in the current situation is that they are seriously affected by adverse meteorological conditions[20].

Strong winds, precipitation and unexpected obstacles reduce the mission performance of the platform considerably, and even many flying cars cannot even fly under some conditions. In this context; During the design phase, all evenings should be evaluated according to the determined needs and conditions and the choices should be made by considering the alternatives. "Drotek Digital Air Velocity Sensor" will be used in order to measure strong air flows accurately. The biggest advantage of being digital is that it can make more reliable and qualified measurements compared to analog sensor data. In addition, it has high sensitivity in terms of the number of data it processes per second. Thanks to the static pressure sensor inside, it also 
increases the data quality by measuring the air temperature. Another system to be used to meet basic security needs is "optical flow". Optical Flow uses a camera with a wide viewing angle on the platform and a distance sensor (lidar for high precision) for position estimation. Optical Flow based navigation and "do not detect" system can be connected via MAVLink, I2C or any bus that supports peripherals. System integration and parameter editing can be done through Optical_Flow_Road and Distance_Sensor options. Other issues to be examined about Optical Flow are EKF and LPE. Although it is healthy enough to examine the parameters determined in order to find rotations and estimation and to do the stabilization in this way, to get to the bottom of the subject, mathematical models and estimation methods are also examined by making a literature review on EKF (Extended Kalman Filter). In addition to these two basic safety issues, the parameter references in the pixhawk developer guide (devel-oper guide) and their operating ranges have been examined in detail in order to determine the working ranges of the sensor data regarding motor power, battery status, position, direction and angle. The improvements to be made regarding the methods chosen while creating the sub-systems will be made by following two different methods. 1. Method is Pixhawk and Linux based simulation environment Gazeboo, and secondly, data of similar platforms on pixhawk review platform, where all users using pixhawk can share their flight / driving logs, have been examined and will continue to be examined. These logs allow us to make detailed comments about the responses of many different sensors and aerodynamic structures under thousands of different conditions[21].

\subsection{Original Value}

It was planned to be done in this field by examining the work done in this long period from the first studies in this field to the present in the world, or it was planned to be done in this field, or it was made in the framework of different logics that could cause both hardware and software deficiencies and security violations in all other flying car designs. Considering all kinds of designs, we aimed to create a unique design as a team. 4G telemetry system, user-friendly control software, unique propeller structure and hybrid battery trials are examples.

The high resolution and 360-degree imaging system we have chosen in our design is supported by imaging software that has image processing capability in order to both meet user requests and increase the level of security. 4G / 5G telemetry systems are used on UAVs. The biggest problem of these systems used is that $4 \mathrm{G}$ infrastructure is dynamic, so they cannot provide a stable connection. Static IP method has been used to solve this problem. Although it is slightly higher than Dynamic IP in terms of cost, it makes a serious difference in terms of performance of the communication and when it comes to security, this financial burden can be ignored. Another work planned to be carried out will be to switch to the e-simcard application, which has recently become widespread, instead of the sim card, which will be used to provide internet access for the vehicle. Thanks to the vehicle being connected to the internet, the information from the vehicle's sensors will be collected in a database. Thanks to this sensor data, the user will be able to access information about the peroformance of the vehicle and the life of the vehicle will be longer with this method. Routes previously saved in the database can be examined and, if necessary, 5 routes will be added to the frequently used routes. Another issue related to route creation is the Dynamic Route Calculation system. Even though alternatives are created in the navigation systems used in mobile phones or in vehicles, these routes have a slightly higher margin of error, especially on long roads. Thanks to the road analysis system to be added to the map service of the vehicle, a selection can be made according to the duration and fuel consumption without neglecting the security conditions. However, if there is unusual traffic on the route or if there is a change in weather conditions, it will be able to update the route instantly by giving a warning. None of the features specified in this section have been encountered in vehicles currently in production in the literature review for flying car designs.

\subsection{Reliability of Power-Propulsion-Propulsion Systems}

Many different power and propulsion systems are used in today's aircraft. As in every mechanical system, the reliability of every system to be used in flying car design should be considered, and accordingly, the most appropriate system that will not endanger human life should be designed. Based on this principle, we have predicted that the most basic element in our flying car design study that may pose a risk to human life is that the components we use in the power and propulsion systems will threaten the life of the external environment in cases such as rupture and ejection from the vehicle as a result of certain malfunctions or burn out as a result of a malfunction. In order to avoid such negative situations, a protection platform will be placed around the propellers and other similar sharp-edged parts connected to the engines used in the design, preventing them from being thrown out of the vehicle in case of any rupture, and at the same time not causing loss of efficiency by damaging the aerodynamic structure of the vehicle. The internal structure of this platform will be completely covered with non-combustible material and a possible fire will be prevented. In addition, in the control station software of our flying car design, it will gradually disable the problematic section and provide the necessary warnings and instructions to the user through the control panels in the cabin for landing to the closest suitable location (if in the air).

\subsection{Magnetic Sensors}

Magnetic sensors are sensors that can measure the magnetic values of the field they are in. Due to these features, direction information can be obtained by using them instead of mechanical compasses. Magnetic sensors; It is used to sense the presence, strength and direction of the magnetic field [22].

Just as a magnet can create a magnetic field, current flowing through a conductor can also create a magnetic field. The direction of the magnetic field passing through the conductor can be determined by the right hand rule as explained in physics and hand-electromagnetic theory lessons. It is possible to find different sensitivity types according to the usage areas of the sensors. Sensors with different structures have been designed to measure the magnetic field. Magnetic sensors contain AMR (Anisotropic Magnetoresistance) materials whose resistance changes in the magnetic field. The direction of the current changes depending on the direction of the magnetic field. The direction of the magnetic field is determined according to the direction of the current, and the intensity of the current changes in proportion to the strength of the magnetic field[23]. Earth's magnetic field is around 0.6 gauss, it takes different values on the earth's surface. The earth's rotation axis determines the geographic north and south poles for the map reference to be used. In order to calculate the direction angle with magnetic 
sensors, the sensor should be positioned parallel to the earth's surface, there should not be any substance in the environment that could affect the earth's magnetic field and the magnetic deviation of the current position should be known. Sensing elements are combined in the form of a wheatstone bridge, with this connection method, the strength and direction of the magnetic field can be calculated. As soon as current flows through a conductor, create a magnetic field around it. Similarly, current occurs on a conductor exposed to a magnetic field. There are structures within the sensor that will sense the magnetic field that varies according to the number of axes. When these structures are exposed to a magnetic field, they determine the value of the magnetic field according to the current value on it.

Accelerometer and Gyroscope can be combined with various methods. The best method is to stay filter. There are also proportional combining methods other than the Kalman filter. In this thesis, using Accelerometer and Gyroscope together, the angles formed in the $\mathrm{X}$ and $\mathrm{Y}$ axes called pitch and roll were determined using the proportional combination method. With the angles obtained, undesired state values occurring at magnetic sensor outputs were normalized. First of all, the pitch and roll angles shown in Figure 3-26 need to be calculated. This calculation is made by proportional combination of angles calculated with Accelerometer and Gyroscope. In the sections where accelerometer and gyroscope sensors are explained, it is explained how angles are calculated with these sensors. The combination of accelerometer and gyroscope angles is made according to the following equations.

Pitch $=($ rate $*($ Pitch + GyroPitch $)+((1-$ rate $) *$ AccPitch $)$

Roll $=($ rate $*($ Roll + GyroRoll $)+((1-$ rate $) *$ AccRoll $)$

Gyropitch and Gyroroll refers to angles calculated with gyroscopes and angles calculated with accelerometers. The "ratio" given as a coefficient in the formula is the coefficient indicating how much to trust which sensor. This ratio differs according to the application and is determined by determining the ideal value in order to calculate the necessary deviations. After calculating the pitch and roll (angles, the new values of the $\mathrm{X}$ and $\mathrm{Y}$ values taken from the magnetic sensor using these angles can be determined through the following equation.

$X E M m a g=X M m a g * \cos +Y M m a g * \sin * \sin -Z M m a g *$ $\cos * \sin$

YEM mag $=$ YM mag $* \cos +Z M m a g * \sin$

\section{Results, Conclusions Recommendations}

The flying car weight distribution is given in table 3 . The chord line lengths and wingspan of the forward and rear wings of the flying car are given in table 4 . In Table 5, lift and drag forces of the flying car at speeds of $15,30,45$ and $60 \mathrm{~m} / \mathrm{s}$ are given.
Table 3. Flying car weight distribution

\begin{tabular}{|l|l|}
\hline VTOL engine & $6800 \mathrm{~g}$ \\
\hline Body weight & $5500 \mathrm{~g}$ \\
\hline Battery & $4825 \mathrm{~g}$ \\
\hline Propulsion engine & $1500 \mathrm{~g}$ \\
\hline Payload & $90000 \mathrm{~g}$ \\
\hline Total weight & $108625 \mathrm{~g}$ \\
\hline
\end{tabular}

Table 4. Forward and rear wing features

\begin{tabular}{|l|l|l|}
\hline \multicolumn{3}{|c|}{ Wing Features } \\
\hline Forward Wing & Chord $(\mathrm{mm})$ & Wingspan $(\mathrm{mm})$ \\
\hline Rear Wing & 250 & 1770 \\
\hline
\end{tabular}

Table 5. Lift and drag force

\begin{tabular}{|l|l|l|l|l|}
\hline Velocity & $15 \mathrm{~m} / \mathrm{s}$ & $30 \mathrm{~m} / \mathrm{s}$ & $45 \mathrm{~m} / \mathrm{s}$ & $60 \mathrm{~m} / \mathrm{s}$ \\
\hline Lift Force & $146 \mathrm{~N}$ & $585 \mathrm{~N}$ & $1317 \mathrm{~N}$ & $2341 \mathrm{~N}$ \\
\hline Drag Force & $1,7 \mathrm{~N}$ & $6,8 \mathrm{~N}$ & $15,36 \mathrm{~N}$ & $27,3 \mathrm{~N}$ \\
\hline
\end{tabular}

In Tables 4 and 5, some technical features of our electric vehicle and the carrying forces it will produce at different speeds are given. Here, the total weight of our electric vehicle is approximately $110 \mathrm{~kg}$, and the forward wing and rear wing veter lengths are 25 and $30 \mathrm{~cm}$. When the forward thruster engines of our vehicle, which is thought to be lifted as vtol, begin to become active, it will begin to gain a certain speed and our wings will gradually load our load due to our wing structure. Our electric vehicle will have a load carrying capacity of 14-230 $\mathrm{kg}$ with the numerical analysis we have done in the speed range of $15-60 \mathrm{~m} / \mathrm{s}$. When the data in the table is examined, when our vehicle reaches a speed of approximately $40 \mathrm{~m} / \mathrm{s}$, it will be able to continue its cruise flight without the need for vtol engines.

Figure 3 shows the static analysis results of the flying car and figure 4 shows the speed analysis on the $\mathrm{Y}$ axis.

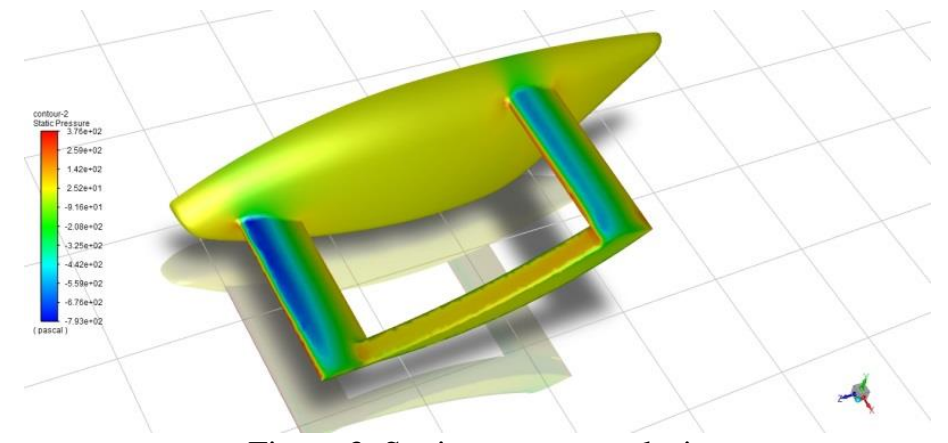

Figure 3. Static pressure analysis 


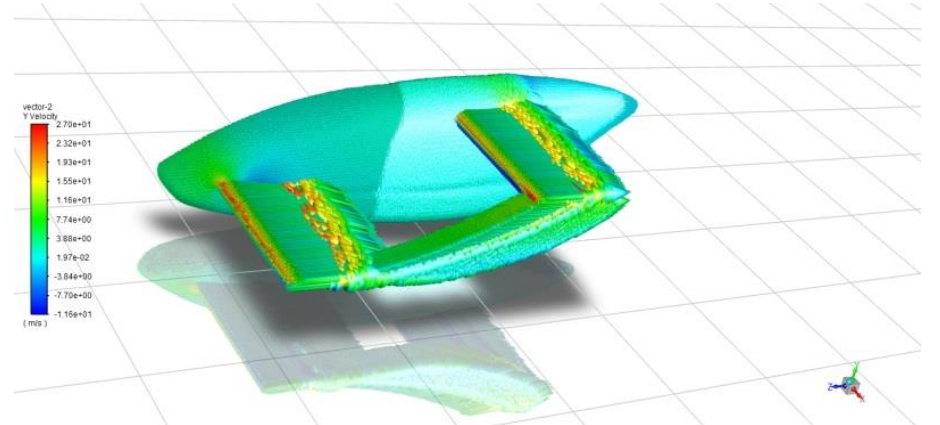

Figure 4. Speed analysis on the $\mathrm{Y}$ axis

The technical features of our flying car are given in detail in the above sections, while the front wing veter used here is $25 \mathrm{~cm}$, the rear wing has been chosen as $30 \mathrm{~cm}$ in terms of stability control. In our flying car, we have 4 vtol engines and 2 propulsion engines. Until our flying car gains its own weight with the wing carrying force, the vtol engines will continue to work by gradually decreasing. Table 5 shows how much bearing force and drag force are effective at different speeds, here it is seen that vtol motors will completely shut down when they reach a speed of $40 \mathrm{~m} / \mathrm{s}$. While the maximum value of drag force is $2.7 \mathrm{~kg}$, the total thrust of our propulsion motors has been selected as $4 \mathrm{~kg}$. For this reason, our aircraft has enough power to carry and push.

\section{References}

[1] Kenaroğlu, Y. (2013). İnsansız Hava Aracı Ne Kadar Güvenilir? Engineer \& the Machinery Magazine, (636).

[2] Arıca, N., Cicibaş, H., \& Demir, K. A. (2012). İnsansız Hava Araçları için Çok Kriterli Güzergâh Planlama Modeli. Savunma Bilimleri Dergisi, 11(1), 251-270.

[3] Demir, K. A., Cicibaş, H., \& Arıca, N. İnsansız Hava Araçları İçin Modüler Bir Simülasyon Tasarım Örneği.

[4] Dursun, M., \& Aksöz, A. İnsansız Bir Hava Aracı Modelinin Üç Boyutlu Tasarımı Analizi ve Simülasyonu.

[5] Bayraktar, O., Özdemir, F., Çetin, Ö., \& YILMAZ, G. (2012). İnsansız Hava Araçları İçin Otonom İniş Sistemi Simülatörü Tasarımı. Bilişim Teknolojileri Dergisi, 5(2), 1-8.

[6] Hadi, G. S., Varianto, R., Trilaksono, B., \& Budiyono, A. (2014). Autonomous UAV system development for payload dropping mission. The Journal of Instrumentation, Automation and Systems, 1(2), 72-22.

[7] Çoban, S. (2019). Different Autopilot Systems Design For a Small Fixed Wing Unmanned Aerial Vehicle. Avrupa Bilim ve Teknoloji Dergisi, (17), 682-691.

[8] Başak, H., \& Gülen, M. (2010). İnsansız Hava Aracı Kazalarının Önlenmesi İçin Risk Ölçümü Ve Yönetimi Modeli. Pamukkale Üniversitesi Mühendislik Bilimleri Dergisi, 14(1), 55-65.

[9] Sarıkurt, T., \& Balıkçı, A. (2017). Tam Elektrikli Araçlar için Özgün Bir Enerji Yönetim Sistemi Uygulamas1. Gazi Üniversitesi Mühendislik-Mimarlık Fakültesi Dergisi, 32(2).

[10] Kök, T. (2012). İnsansız Hava Araçlarının Güvenli Kullanımı için Spektrum İhtiyaçlarının Belirlenmesi ile İlgili Öneriler. Teknik Uzmanlık Tezi), İstanbul, Bilgi Teknolojileri ve İletişim Kurumu.
[11] Yumruktay, M. K. (2015). GNSS destekli prototip otonom araç tasarımı.

[12] Oktay, T., \& Coban, S. (2017). Lateral autonomous performance maximization of tactical unmanned aerial vehicles by integrated passive and active morphing. International Journal of Advanced Research in Engineering, 3(1), 1-5.

[13] Çoban, S. (2020). Autonomous performance maximization of research-based hybrid unmanned aerial vehicle. Aircraft Engineering and Aerospace Technology.

[14] Önal, M., Çoban, S., Yapıcı, A., \& Bilgiç, H. H. Dikey İniş Kalkış Yapabilen Bir İHA’nın Azami Menzili ve Asgari Güç Gereksinimi İçin En Uygun Uçuş Parametrelerinin Belirlenmesi. Journal of Aviation, 3(2), 106-112.

[15] Uysal, A. (2008). Rüzgar türbini kanat malzemelerinin mekanik özelliklerinin incelenmesi.

[16]www.cfdonline.com/Wiki/Y_plus_wall_distance_estimation (Date of access: Mart 2020)

[17] John D. Anderson J., 2010. Fundamentals of Aerodynamics, McGraw-Hillseries in aeronautical and a erospace engineering. $\mathrm{s}: 1104$

[18] Lee, B., Park, P., Kim, C., Yang, S., \& Ahn, S. (2012). Power managements of a hybrid electric propulsion system for UAVs. Journal of mechanical science and technology, 26(8), 2291-2299.

[19] Lieh, J., Spahr, E., Behbahani, A., \& Hoying, J. (2011, August). Design of hybrid propulsion systems for unmanned aerial vehicles. In 47th AIAA/ASME/SAE/ASEE Joint Propulsion Conference \& Exhibit (p. 6146).

[20] Maza, I., Caballero, F., Capitán, J., Martínez-de-Dios, J. R., \& Ollero, A. (2011). Experimental results in multi-UAV coordination for disaster management and civil security applications. Journal of intelligent \& robotic systems, 61(1), 563-585.

[21] Dursun, M., \& Çuhadar, İ. (2018). Secure Video Streaming Implementation for Unmanned Air Vehicle (UAV) Data Link with Raspberry Pi 3 over https. Bilişim Teknolojileri Dergisi, 11(1), 23-28.

[22] Sigurd, K., \& How, J. (2003, August). UAV trajectory design using total field collision avoidance. In AIAA Guidance, Navigation, and Control Conference and Exhibit (p. 5728).

[23] Eck, C., \& Imbach, B. (2011). Aerial magnetic sensing with an UAV helicopter. International Archives of the Photogrammetry, Remote Sensing and Spatial Information Sciences, 38(1/C22). 